\title{
Parámetros genéticos para producción de leche de ganado Holstein en dos modalidades de control de producción
}

\section{Estimation of genetic parameters for milk production in Holstein cattle in Mexico under two modes of production control}

\author{
Hugo O. Toledo Alvaradoa, Felipe de Jesús Ruiz Lópezb, Carlos G. Vázquez Peláeza, \\ José M. Berruecos Villalobosa, Mauricio A. Elzoc
}

\begin{abstract}
RESUMEN
Se estimaron componentes de varianza y parámetros genéticos para producción de leche total a la primera lactancia (PL1), producción de leche ajustada a 305 días y a equivalente adulto de la primera lactancia (PL1std), producción de leche total de las cinco primeras lactancias (PL5) y producción de leche ajustada a 305 días y a equivalente adulto de las primeras 5 lactancias (PL5std). Se utilizaron las bases de datos de la Asociación Holstein de México (AHM; $n=43,668)$ y del Banco Nacional de Información Lechera $(B N I L ; n=120,217)$. Las varianzas fueron estimadas mediante REML, utilizando un modelo animal simple para PL1 y PL1std y un modelo animal de repetibilidad para PL5 y PL5std. Las heredabilidades estimadas fueron desde bajas a moderadas para la primera lactancia $(0.17 \pm 0.009$ a $0.49 \pm 0.019)$ y para las primeras cinco lactancias $(0.16 \pm 0.006$ a $0.41 \pm$ 0.004). Las repetibilidades para PL5 y PL5std tuvieron un rango de $0.32 \pm 0.002$ a $0.41 \pm 0.004$. La inclusión de la información del BNIL en las evaluaciones genéticas permitió incorporar datos de producción que no se estaban tomando en cuenta. Esto no solamente mejoró la precisión de los valores genéticos de los sementales para producción de leche, sino que también permitió la predicción de los valores genéticos de animales nacionales y extranjeros con progenies en México.
\end{abstract}

PALABRAS CLAVE: Heredabilidad, Repetibilidad, Holstein, Producción de leche, México.

\begin{abstract}
Variance components and genetic parameters were estimated for total milk production at first lactation (MP1), milk yield adjusted to $305 \mathrm{~d}$ and adult equivalent at the first lactation (MP1std), total milk production of the first five lactations (MP5) and milk yield adjusted to $305 \mathrm{~d}$ and mature equivalent of the first five lactations (MP5std). The databases of the Mexican Holstein Association (MHA, $n=43,668$ ) and of the National Bank of Dairy Information (NBDI, $n=120,217$ ) were used. Variances were estimated by REML, using a simple animal model for MP1 and MP1std and a repeatability animal model for MP5 and MP5std. Heritability estimates ranged from low to moderate for the first lactation $(0.17 \pm 0.009$ to $0.49 \pm 0.019)$ and for the first five lactations $(0.16 \pm 0.006$ to $0.41 \pm 0.004)$. The repeatabilities for MP5 and MP5std ranged from $0.32 \pm 0.002$ to $0.41 \pm 0.004$. The inclusion of information of the NBDI on the national evaluations made possible the incorporation of production data that had not been taken into consideration before. This inclusion not only improved the accuracy of sire breeding values for milk production, but also allowed the prediction of breeding values of more foreign and domestic animals with progeny in Mexico.
\end{abstract}

Recibido el 31 de agosto de 2012. Aceptado el 17 de enero de 2013.

a Departamento de Genética y Bioestadística, Facultad de Medicina Veterinaria y Zootecnia, Universidad Nacional Autónoma de México. Av. Universidad 3000, Copilco el Alto 04510. México DF. México. h.toledo.a@gmail.com. Correspondencia al primer autor.

b Centro Nacional de Investigación en Fisiología y Mejoramiento Animal. INIFAP-SAGARPA. México.

c Department of Animal Sciences, University of Florida, Gainesville, USA. 
KEY WORDS: Heritability, Repeatability, Holstein, Milk production, Mexico.

La estimación de varianzas y covarianzas genéticas y fenotípicas es necesaria para poder predecir los valores genéticos de la cría y así poder implementar programas de mejoramiento sobre características de interés económico $(1,2)$. La producción láctea ha sido el principal criterio de selección en bovinos productores de leche en México por su relación directa con los retornos económicos de los productores $(3,4)$. Este carácter ha sido utilizado frecuentemente en evaluaciones genéticas e índices de selección en combinación con características de reproducción, conformación, funcionales y longevidad(5,6). El rango de heredabilidades estimadas en ganado Holstein en México es de 0.13 a $0.57(6-9)$ para la producción de leche a primer parto, y el rango de repetibilidades es de 0.32 a 0.52 para producciones de leche hasta el tercer parto $(9,10,11)$.

La Asociación Holstein de México (AHM) y el Centro Nacional de Investigación en Fisiología y Mejoramiento Animal del Instituto Nacional de Investigaciones Forestales, Agrícolas y Pecuarias (INIFAP) realizan las evaluaciones genéticas para la población de ganado Holstein registrada ante la asociación. Sin embargo, en el año 2008 se inició el Programa Nacional de Mejoramiento Genético de Bovinos Productores de Leche (PNMG) en México, auspiciado por la Secretaria de Agricultura, Ganadería, Desarrollo Rural, Pesca y Alimentación (SAGARPA) en convenio para su operación por la AHM. El PNMG tiene como objetivo realizar programas de mejoramiento genético y aumentar la rentabilidad de los establos, creando bases de datos nacionales con información genealógica, productiva y reproductiva de establos lecheros del país. El PNMG incluye un Banco Nacional de Información Lechera (BNIL) y cuenta con información de ganaderías productoras de leche en diferentes partes del país, que no está incluida en estas evaluaciones por no contar con información genealógica y productiva validada por la $\operatorname{AHM}(12)$. Lo anterior implica que no se ha utilizado toda la información
Estimating variances and genetic and phenotypic covariance is needed to predict genetic values of the offspring and thus implement breeding programs on traits of economic interest $(1,2)$. Milk production has been the main criterion for selection in dairy cattle producers in Mexico because of its direct relationship to the economic returns to producers $(3,4)$. This character has been frequently used in genetic evaluations and index selections in combination with reproduction characteristics, conformation, functional and longevity $(5,6)$. The range of heritabilities estimations in Holstein cattle in Mexico is 0.13 to $0.57(6,9)$ for the production of milk at first calving, and the repeatability range goes from 0.32 to 0.52 for milk production until the third calving $(9,10,11)$.

The Mexican Holstein Association (MHA) and the National Research Center for Physiology and Animal Breeding of the National Institute of Forestry, Agriculture and Livestock (INIFAP) perform genetic evaluations for Holstein cattle population registered with the association. However, in 2008 started the National Breeding Program of Dairy cattle (NBPD) in Mexico, sponsored by the Secretariat of Agriculture, Livestock, Rural Development, Fisheries and Food in agreement for operation with MHA. The NBPD aims to make breeding programs and increase the profitability of the stables, creating national databases with genealogical, productive and reproductive information of dairy farms in the country. The NBPD includes a National Bank of Dairy Information (NBDI) that has information about dairy herds in different parts of the country, which is not included in these evaluations because they lack of productive and genealogical information validated by the $\mathrm{MHA}^{(12)}$. This implies that all information available has not been used for the evaluation of Holstein animals in Mexico, so it is important to include this additional information and assess their impact on national genetic evaluations, comparing the estimated genetic parameters for milk production without additional information. 
disponible para la evaluación de animales Holstein en México, por lo que es importante incluir esta información adicional y evaluar su impacto sobre las evaluaciones genéticas nacionales, comparando los parámetros genéticos estimados para producción de leche con y sin la información adicional.

Los objetivos de este estudio fueron: 1) estimar la variabilidad genética aditiva y la heredabilidad de la producción de leche total y estandarizada (305 días, equivalente adulto) para la primera lactancia en las tres poblaciones: AHM, BNIL y PNMG (AHM y BNIL juntas); 2) estimar las variabilidades genética aditiva y de ambiente permanente y sus correspondientes parámetros (heredabilidad y repetibilidad) para producción de leche total y estandarizada considerando las primeras cinco lactancias por vaca en las tres poblaciones: AHM, BNIL y PNMG; 3) comparar la precisión de los valores genéticos aditivos y el ordenamiento de los sementales en común en estas tres poblaciones.

Se utilizaron las bases de datos del BNIL (Control de producción en muestreo por ganadero) y de la Asociación de Criadores Holstein de México (Control de producción oficial de la asociación) $\mathrm{AHM}$, que conjuntamente conforman el PNMG y cuentan con información de 437,058 lactaciones entre los años 2007 al 2011 con información de producción y genealogía. Las bases de datos finales contabilizaron un total de 120,217 vacas hijas de 1,528 sementales para BNIL, de los cuales 66 tenían registro mexicano. La población AHM se conformó por 43,668 vacas hijas de 767 sementales, de los cuales 119 tenían registro mexicano. Uniendo las dos bases en el Programa Nacional de Mejoramiento Genético (PNMG) se tuvieron 163,885 vacas hijas de 1,694 sementales con 601 sementales con hijas en ambas bases de datos. Para estimar los componentes de varianza se crearon tres archivos de pedigrí, uno para cada set de datos, incluyendo todos los individuos disponibles. El BNIL tuvo 250,282 registros de pedigrí, mientras que la AHM contó con 124,044 y el PNMG 368,827. Se utilizaron
The objectives of this study were 1) to estimate the additive genetic variability and heritability of total production and standardized milk (305 d, adult equivalent) for first calving in three populations: MHA, NBDI and NBPD (MHA and NBDI together), 2) to estimate additive and permanent environmental genetic variability and its corresponding parameters (heritability and repeatability) for the production of complete and standardized milk considering the first five lactations per cow in the three populations: MHA, NBDI and NBPD, and 3) compare the accuracy of the additive genetic values and arrange of sires in common in these three populations.

There were used databases of NBDI (production control sampling by farmer) and Holstein Breeders Association of Mexico (Official Production Control by Association) MHA, which together make up the NBPD and joint information of 437,058 lactations between the years 2007 to 2011 with production information and genealogy. The final databases counted a total of 120,217 cows daughters of 1,528 sires of NBDI, of which 66 were Mexicans. The MHA population was formed by 43,668 cows daughters of 767 sires, of whom 119 were Mexicans. Uniting the two bases at the National Breeding Program (NBPD) there were 163,885 cows, daughters of 1,694 sires with 601 sires with daughters in both databases. To estimate the variance components three pedigree files were created, one for each set of data, including all available individuals. The NBDI pedigree had 250,282 records, while the MHA had 124,044 and the NBPD 368,827 . Milk production records with information from the first five lactations were used.

The variables analyzed were total cumulative production and production standardized to adult equivalent, two milkings and $305 \mathrm{~d}$. Records of cows or progenitors where breed was different to Holstein were removed; records with lower production to $1,500 \mathrm{~kg}$ of milk (lactations considered abnormal), and animals under 18 mo of age at birth. In addition, animal records 
registros de producción de leche con información de las primeras cinco lactancias.

Las variables analizadas fueron la producción total acumulada y la producción estandarizada a equivalente adulto, dos ordeñas y 305 días. Se eliminaron registros de vacas o progenitores con razas diferentes a la Holstein; registros con producciones menores a $1,500 \mathrm{~kg}$ de leche (por considerarse lactancias anormales), y animales con menos de 18 meses de edad al parto. Así mismo se eliminaron registros de animales con menos de 90 días en lactación para asegurar al menos tres pesajes. Las bases de datos y los archivos de pedigrí se editaron con un programa escrito en lenguaje C\#(13) y el Sistema de Análisis Estadístico (SAS)(14). Los datos provinieron de 155 hatos cuya producción representa el $14 \%$ de la producción nacional láctea, y que están ubicados en 22 estados de la República Mexicana: Aguascalientes, Baja California, Coahuila, Chiapas, Chihuahua, Durango, Guerrero, Guanajuato, Hidalgo, Edo. de México, Jalisco, Michoacán, Morelos, Nayarit, Oaxaca, Puebla, Querétaro, San Luis Potosí, Sinaloa, Tlaxcala, Veracruz y Zacatecas(12). De los 22 estados representados, dos se clasificaron con clima seco desértico, seis con clima seco estepario, cuatro con cálido húmedo, dos con cálido semi-humedo y ocho con templado semihumedo. El clima seco desértico se caracteriza por una oscilación térmica entre los 0 y los 40 ${ }^{\circ} \mathrm{C}$, y una precipitación menor a los $400 \mathrm{~mm}$ por año en verano. El clima seco estepario tiene una temperatura media anual de $18{ }^{\circ} \mathrm{C}$ con una amplitud térmica de $10^{\circ} \mathrm{C}$, y presentan una precipitación anual menor a los $750 \mathrm{~mm}$ en verano. En el clima cálido húmedo la temperatura media anual es de 18 a $21^{\circ} \mathrm{C}$, con precipitaciones de 750 a 1,500 mm anuales en todo el año. En tanto que el clima cálido semi-humedo tiene las mismas características que el cálido húmedo pero las lluvias se tienen sólo en verano. El clima templado semi-humedo mantiene un promedio de temperatura de 12 a $18^{\circ} \mathrm{C}$ y precipitaciones anuales de 600 a 1,500 $\mathrm{mm}$ en verano(15). with less than $90 \mathrm{~d}$ in milking were removed to ensure at least three weightings. Databases and pedigree files were edited with a program written in C\# language(13) and the Statistical Analysis System (SAS)(14). Data came from 155 herds whose production represents $14 \%$ of milk national production, and which are located in 22 States of Mexico: Aguascalientes, Baja California, Coahuila, Chiapas, Chihuahua, Durango, Guerrero, Guanajuato, Hidalgo, Estado de Mexico, Jalisco, Michoacan, Morelos, Nayarit, Oaxaca, Puebla, Querétaro, San Luis Potosí, Sinaloa, Tlaxcala, Veracruz and Zacatecas(12). Of the 22 states represented, two were classified dry desert climate, six with dry steppe climate, four hot and humid, two warm semi-humid and eight with semi-humid temperate. The dry desert climate is characterized by a temperature variation between 0 and $40^{\circ} \mathrm{C}$, and less than $400 \mathrm{~mm}$ rainfall per year in summer. The dry steppe climate has an average temperature of $18 \mathrm{C}$ with a temperature range of $10^{\circ} \mathrm{C}$ and has a lower annual rainfall of $750 \mathrm{~mm}$ in summer. In the warm humid climate the average temperature is 18 to $21^{\circ} \mathrm{C}$, with rainfall from 750 to $1,500 \mathrm{~mm}$ per year in the whole year. While the semi-humid warm weather has the same features as the moist warm but rains only at summer. The semi-humid temperate maintains an average temperature of 12 to 18 ${ }^{\circ} \mathrm{C}$ and annual rainfall of 600 to $1,500 \mathrm{~mm}$ in summer(15).

To represent the effects of time, two stations were defined: December to May (Season 1), and from June to November (Season 2) according to the presence of summer rains: The factors herd-year-season of birth effect was created. Systems management and feeding were varied and generally were intensive type.

The diet was based mostly in cut and carry fodder, silage, hay and concentrates with mineral supplementation. The main forage crops used were alfalfa (Medicago sativa), corn (Zea Mays), forage sorghum (Sorghum vulgare), oats (Avena sativa) and ryegrass (Lolium spp.), white clover (Trifolium repens), kikuyu grass (Pennisetum 
Para representar los efectos de época, se definieron dos estaciones: de diciembre a mayo (estación 1), y de junio a noviembre (estación 2) de acuerdo a la presencia de lluvias en verano. Se creó un efecto combinando los factores hato-año-estación de parto. Los sistemas de manejo y alimentación fueron muy variados y en general de tipo intensivo. La alimentación estuvo basada en su mayoría en forrajes de corte y acarreo, silo, heno y concentrados con suplementación de minerales. Los principales cultivos forrajeros utilizados fueron alfalfa (Medicago sativa), maíz (Zea Mays), sorgo forrajero (Sorghum vulgare), avena (Avena sativa) y ryegrass (Lolium spp.), trébol blanco (Trifolium repens), pasto Kikuyo (Pennisetum clandestinum) y pastos nativos. La producción de forraje y el manejo animal fueron altamente mecanizados. Se utilizaron sistemas como el de Ración Mezclada Total (RMT) y se aprovecharon productos locales de residuos de cultivos y sub-productos industriales $(16,17)$.

Se estimaron componentes de varianza genéticos aditivos, ambientales permanentes y clandestinum) and native grasses. Forage production and animal management were highly mechanized. Systems such as Total Mixed Ration (TMR) were used; crop residues of local products and industrial sub-products were also exploited(16,17).

Additive genetic variance components, permanent environmental and residual were estimated with Restricted Maximum Likelihood method(18) using an average information algorithm(19). The ASREML program was used to perform the calculations(20). The convergence criterion was reached when the value of the logarithm of maximum likelihood changed less than 0.0002 in three successive iterations(20). The fixed and random effects included in the models are presented in Table 1 . Mixed model used for total milk production for first lactation (MP1) and for the production of standardized milk $305 \mathrm{~d}$ and adult eauivalent first lactation (MP1std) was(21,22): $y=X b+Z u+e$

$\left[\begin{array}{l}y \\ u \\ e\end{array}\right] \sim M V N\left\{\left[\begin{array}{c}X \beta \\ 0 \\ 0\end{array}\right],\left[\begin{array}{ccc}Z G Z^{\prime}+R & G Z^{\prime} & R \\ G Z^{\prime} & G & 0 \\ R & 0 & R\end{array}\right]\right\}$

Cuadro 1. Efectos fijos y aleatorios incluidos en los modelos para estimar los componentes de varianza de los cuatro caracteres en este estudio

Table 1: $\quad$ Fixed and random effects included in the models to estimate the variance components of the four characters in this study

\begin{tabular}{lll}
\hline Model & Characteristic & Efects \\
\hline 1 & $\begin{array}{l}\text { Total milk production in the } \\
\text { 1st lactation (MP1) }\end{array}$ & $\begin{array}{l}\text { Fixed: Herd-year-season, type of milking (2x or 3x), } \\
\text { days in milk (linear and quadratic) age at calving } \\
\text { (linear and quadratic); Random: animal }\end{array}$ \\
2 & $\begin{array}{l}\text { Milk production standardized } \\
\text { 305-d and adult equivalent of } \\
\text { 1st lactation (MP1st) }\end{array}$ & Fixed: Herd-year-season; Random: animal \\
3 & $\begin{array}{l}\text { Total milk production of the } \\
\text { first } 5 \text { lactations (MP5) }\end{array}$ & $\begin{array}{l}\text { Fixed: Herd-year-season, type of milking (2x or 3x), lactation } \\
\text { number, days in milk (linear and quadratic) age at calving } \\
\text { (linear and quadratic); Random: animal, permanent environment. }\end{array}$ \\
& $\begin{array}{l}\text { Milk production standardized } \\
\text { 305-d adult equivalent of the } \\
\text { first 5 lactations (MP5std) }\end{array}$ & $\begin{array}{l}\text { Fixed: Herd-year-season; Random: animal, } \\
\text { permanent environment. }\end{array}$ \\
\hline
\end{tabular}


residuales con el método de Máxima Verosimilitud Restringida(18) utilizando un algoritmo de información promedio(19). Se usó el programa ASREML para realizar los cómputos(20). El criterio de convergencia se alcanzó cuando el valor del logaritmo de máxima verosimilitud cambió menos de 0.0002 en tres iteraciones sucesivas(20). Los efectos fijos y aleatorios incluidos en los modelos se presentan en el Cuadro 1. El modelo mixto utilizado para la producción de leche total a la primera lactancia (PL1) y para la producción de leche estandarizada a 305 días y a equivalente adulto de la primera lactancia (PL1std), fue $(21,22)$ : $y=X b+Z u+e$

$\left[\begin{array}{l}y \\ u \\ e\end{array}\right] \sim M V N\left\{\left[\begin{array}{c}X \beta \\ 0 \\ 0\end{array}\right],\left[\begin{array}{ccc}Z G Z^{\prime}+R & G Z^{\prime} & R \\ G Z^{\prime} & G & 0 \\ R & 0 & R\end{array}\right]\right\}$

Donde: $y=$ vector de observaciones de PL1 y PL1std de las vacas; $b=$ vector de hato-añoestación (único efecto fijo en PL1std), tipo de ordeña ( $2 x \circ 3 x$ ), así como las covariables edad y días en lactancia en sus formas lineal y cuadrática; $u=$ vector de efectos aleatorios genéticos aditivos individuales de los animales; $e=$ vector de efectos aleatorios residuales; $X=$ matriz de incidencia que relaciona los registros con los elementos de $b ; Z=$ matriz de incidencia que relaciona los registros con los elementos de $u ; G=A \sigma_{a}^{2}$, donde $A=$ es la matriz de relaciones aditivas y $\sigma_{a}^{2}=$ varianza aditiva; y $R=I \sigma_{\theta}^{2}$, donde $I$ es una matriz identidad y $\sigma_{\theta}^{2}=$ varianza residual.

El modelo mixto para la producción de leche total de las cinco primeras lactancias (PL5) y para la producción de leche estandarizada a 305 días y a equivalente adulto de las cinco primeras lactancias (P5Lstd), fue $(21,22)$ : $y=X b+Z u+W p+e$
Where: $y=$ vector of observations for MP1and MP1std of cows; $b=$ vector of herd-year-season (only fixed effect in MP1std), type of milking ( $2 x$ or $3 x)$ and the covariates age and days in milk in their linear and quadratic forms; $u=$ vector of additive genetic random effects individuals of animals; $e=$ vector of residual random effects; $X=$ matrix that associated records with the elements of $b ; Z=$ matrix that relates the records with the elements of $u ; G=$ $A \sigma_{a}^{2}$, where $A$ is the matrix of additive relationships and $\sigma_{a}^{2}=$ additive variance; and $R=$ $I \sigma_{\theta}^{2}$, where $I$ is an identity matrix and $\sigma_{\theta}^{2}=$ residual variance.

The mixed model for total milk production of the first five lactations (MP5) and for the production of standardized milk $305 \mathrm{~d}$ and adult equivalent of the first five lactations (MP5std) was(21,22) : $y=X b+Z u+e$

$\left[\begin{array}{l}y \\ u \\ p \\ e\end{array}\right] \sim M V N\left\{\left[\begin{array}{c}X \beta \\ 0 \\ 0 \\ 0\end{array}\right],\left[\begin{array}{cccc}Z G Z^{\prime}+W P W^{\prime}+R & G Z^{\prime} & P & R \\ G Z^{\prime} & G & 0 & 0 \\ P & 0 & P & 0 \\ R & 0 & 0 & R\end{array}\right]\right\}$

Where: $y=$ vector of observations for MP5 and MP5std of cows; $b=$ vector of herd-year-season (only fixed effect in MP5std), type of milking ( $2 x$ or $3 x$ ), lactation number and the covariates age and days in milk in their linear and quadratic forms; $u=$ vector of additive genetic random effects individuals of animals; $p=$ vector of random permanent environmental effects; $e=$ vector of random residual effects; $X=$ matrix that associate records with the elements of $b$; $Z=$ matrix that relates the records with elements of $u ; W=$ matrix that relates the records with elements in $p ; \mathrm{G}=A \sigma_{a}^{2}$, where $A=$ matrix additive relationships and $\sigma_{a}^{2}=$ additive variance; $P=I \sigma_{\theta}^{2}$, where $I$ is an identity matrix and $\sigma_{p e}^{2}$ is the variance of permanent environment; and $R=I \sigma_{\theta}^{2}$, where $I$ is an identity matrix and $\sigma_{\theta}^{2}=$ residual variance. 
$\left[\begin{array}{l}y \\ u \\ p \\ e\end{array}\right] \sim M V N\left\{\left[\begin{array}{c}X \beta \\ 0 \\ 0 \\ 0\end{array}\right],\left[\begin{array}{cccc}G G Z^{\prime}+W P W^{\prime}+R & G Z^{\prime} & P & R \\ G Z^{\prime} & G & 0 & 0 \\ P & 0 & P & 0 \\ R & 0 & 0 & R\end{array}\right]\right\}$

Donde: $y=$ vector de observaciones de PL5 y PL5std de las vacas; $b=$ vector de hato-añoestación (único efecto fijo en PL5std), tipo de ordeña ( $2 x \circ 3 x)$, número de lactancia, así como las covariables edad y días en lactancia en sus formas lineal y cuadrática; $u=$ vector de los efectos aleatorios genéticos aditivos individuales de los animales; $p=$ vector de efectos aleatorios de ambiente permanente; $e=$ vector de efectos aleatorios residuales; $X=$ matriz de incidencia que relaciona los registros con los elementos de $b ; Z=$ matriz de incidencia que relaciona los registros con los elementos de $u ; W=$ matriz de incidencia que relaciona las registros con los elementos de $p ; G=A \sigma_{a}^{2}$, donde $A=$ matriz de relaciones aditivas y $\sigma_{a}^{2}=$ varianza aditiva; $P=I \sigma_{\theta}^{2}$, donde $I$ es una matriz identidad y $\sigma_{p e}^{2}$ es la varianza del ambiente permanente; y $R=I \sigma_{\theta}^{2}$, donde $I$ es una matriz identidad y $\sigma_{\theta}^{2}=$ varianza residual. Se estimaron heredabilidades para PL1, PL1std y PL5 y PL5std en las poblaciones AHM, BNIL y PNMG. Los valores genéticos de los animales se predijeron usando el método del Mejor Predictor Linear Insesgado usando el programa $\operatorname{ASREML}(14,18,20)$. La precisión de los valores genéticos predichos se definió como la correlación entre la predicción del valor genético de un animal y su valor genético verdadero. La precisión del valor predicho del animal $i$ se calculó como:

precisión $_{i}=\sqrt{\frac{\sigma_{u}^{2}-\operatorname{Var}(\hat{u}-u)}{\sigma_{u}^{2}}}$

Posteriormente se calcularon los promedios y desviaciones estándares de las precisiones para cada set de datos. Se identificaron los sementales en común entre la AHM y el BNIL y se calcularon los promedios y desviaciones
Heritabilities for MP1, MP5 and MP5std MP1std were estimated in the MHA, NBDI and NBPD populations. The breeding values of animals were predicted using the method of Best Linear Unbiased Predictor using the program $\operatorname{ASREML}(14,18,20)$.

The accuracy of predicted breeding values was defined as the correlation between the prediction of the genetic value of an animal and true breeding value. The accuracy of the predicted value of the animal $i$ was calculated as:

accuracy $=\sqrt{\frac{\sigma_{u}^{2}-\operatorname{Var}(\hat{u}-u)}{\sigma_{u}^{2}}}$.

Then the averages and standard deviations of the accuracies for each data set were calculated. Sires in common between the MHA and NBDI were identified and the means and standard deviations of the accuracies of these sires in the MHA, the NBDI, and NBPD were calculated. Breeding values were ordered within each dataset (MHA, NBDI and NBPD) with SAS PROC RANK. The Spearman rank correlation of breeding values was calculated with PROC CORR SPEARMAN procedure of SAS for: 1) All sires in common (MHA, NBDI and NBPD), and 2) For the top $10 \%$ in the population MHA (MHA vs NBDI) NBDI (NBDI vs MHA) and NBPD (NBPD vs MHA and NBPD vs NBDI).

The averages and standard deviations for the variables analyzed are shown in Table 2 . Standardized productions had higher averages than total milk production, which was expected because the total productions include lactations less than $305 \mathrm{~d}$ and the average age (34 mo) was lower to mature age, so the adjustment factors tend to increase the production when standardized. For total milk production variable, the means were higher for the MHA in all lactations, reaching the highest production to third birth in the three data sets. For standardized production, averages were higher for the NBDI except first lactation where the MHA had its greatest standardized production, while NBDI and NBPD showed their highest 
Hugo O. Toledo Alvarado, et al. / Rev Mex Cienc Pecu 2014;5(4):443-457

Cuadro 2. Media, desviación estándar (SD), mínimo y máximo, para la producción de leche de las cinco primeras lactancias para las tres bases de datos

Table 2. Mean, standard deviation (SD), minimum and maximum for milk production of the first five lactations for the three databases

\begin{tabular}{|c|c|c|c|c|c|c|c|c|c|c|c|}
\hline Database & Statistic & MP1 & MP1std & MP2 & MP2std & MP3 & MP3std & MP4 & MP4std & MP5 & MP5std \\
\hline \multirow{4}{*}{$\begin{array}{l}\text { NBDI } \\
(n=120,217)\end{array}$} & Mean & 6308 & 11382 & 7222 & 11663 & 7339 & 11283 & 7171 & 10780 & 7045 & 10455 \\
\hline & SD & 3173 & 2377 & 3075 & 2537 & 3109 & 2483 & 3059 & 2445 & 3065 & 2470 \\
\hline & Minimum & 1500 & 5000 & 1500 & 5000 & 1500 & 5000 & 1500 & 5000 & 1500 & 5000 \\
\hline & Maximum & 34040 & 21000 & 33040 & 21000 & 38900 & 20890 & 32020 & 20420 & 27190 & 18910 \\
\hline \multirow{4}{*}{$\begin{array}{l}\text { MHA } \\
(n=43,668)\end{array}$} & Mean & 9579 & 11724 & 10087 & 11466 & 10342 & 10914 & 10125 & 10310 & 9817 & 9893 \\
\hline & SD & 3907 & 2600 & 3936 & 2950 & 4138 & 2880 & 4221 & 2744 & 4137 & 2618 \\
\hline & Minimum & 1500 & 5000 & 1500 & 5000 & 1500 & 5000 & 1500 & 5000 & 1500 & 5000 \\
\hline & Maximum & 35720 & 21000 & 36550 & 20990 & 35360 & 20830 & 39360 & 19900 & 39520 & 20180 \\
\hline \multirow{4}{*}{$\begin{array}{l}\text { NBPD } \\
(n=163,885)\end{array}$} & Mean & 7179 & 11473 & 7967 & 11612 & 8129 & 11186 & 7977 & 10652 & 7826 & 10297 \\
\hline & SD & 3680 & 2443 & 3550 & 2652 & 3658 & 2598 & 3660 & 2538 & 3623 & 2442 \\
\hline & Minimum & 1500 & 5000 & 1500 & 5000 & 1500 & 5000 & 1500 & 5000 & 1500 & 5000 \\
\hline & Maximum & 35720 & 21000 & 36550 & 21000 & 38900 & 20890 & 39360 & 20420 & 39520 & 20180 \\
\hline
\end{tabular}

$\mathrm{NBDI}=$ Database of the National Bank of Dairy Information, MHA= Database of the Holstein Association of Mexico; NBPD= National program that joints NBDI and MHA. MP1, MP2, MP3, MP4 and MP5= Total milk production from the first five lactations. MP1std, MP2std, MP3std, MP4std and MP5std= Standardized milk productions of the first five lactations.

estándar de las precisiones de esos sementales en la AHM, el BNIL, y el PNMG. Se ordenaron los valores genéticos dentro de cada conjunto de datos (AHM, BNIL, y PNMG) con el procedimiento PROC RANK de SAS. Se calculó la correlación por rangos de Spearman de los valores genéticos con el procedimiento PROC CORR SPEARMAN de SAS para: 1) todos los sementales en común (AHM, BNIL, y PNMG), y 2) después para el $10 \%$ superior dentro de la población AHM (AHM vs BNIL), BNIL (BNIL vs AHM), y PNMG (PNMG vs AHM y PNMG $v s$ BNIL).

Los promedios y desviaciones estándar para las variables analizadas se muestran en el Cuadro 2. Las producciones estandarizadas tuvieron promedios mayores a las producciones totales acumuladas, lo que era esperado porque las producciones totales incluyen lactaciones de menos de 305 días y la edad promedio (34 meses) fue inferior a la edad madura, por lo que los factores de ajuste tienden a incrementar la producción al estandarizarla. Para la variable producción total, los promedios fueron mayores production at the second birth. The fact that the highest standardized productions in the MHA were from first lactation cows, reflects the emphasis that farmers from the association have put on the improvement of this property, which is not observed in the NBDI. Standardization considerably increased NBDI productions, which allowed them to have higher averages from 2nd to 5th lactation regarding the MHA.

In Table 3, the additive, permanent and environmental, residual and phenotypic variances for each of the models are shown. For MP1 and MP1std additive variance was higher for NBDI while for MP5 and MP5std the MHA had the highest additive variance. This is due to a greater variability when choosing sires that are being used in for first calving by the NBDI regarding the MHA. However, in the NBPD the additive variances in all cases were the lowest, because the variability between the studs in the NBPD was also lower. Heritabilities were similar to the MHA because the phenotypic variance also decreased, so the information provided for the MHA has a high influence on 
para la AHM en todas las lactancias, alcanzando la mayor producción al tercer parto en las tres bases. Para la producción estandarizada los promedios fueron mayores para el BNIL, excepto en la primera lactancia, en donde la AHM tuvo su mayor producción estandarizada, mientras que el BNIL y el PNMG mostraron su mayor producción al segundo parto. El que las mayores producciones estandarizadas en la AHM sean las de las vacas de primera lactancia refleja el énfasis que los ganaderos de la Asociación han puesto sobre el mejoramiento de la característica, lo que no se observa en el BNIL. La estandarización aumentó considerablemente las producciones del BNIL, lo que le permitió tener promedios mayores de la 2da a la 5 ta lactancia con respecto a la AHM.

En el Cuadro 3 se muestran las varianzas aditivas, de ambiente permanente, residuales y fenotípicas para cada uno de los modelos. Para PL1 y PL1std la varianza aditiva fue mayor para el BNIL, mientras que para PL5 y PL5std la AHM tuvo la mayor varianza aditiva. Esto se debe a una mayor variabilidad al elegir los sementales que se están utilizando en la primera the evaluations and estimation of genetic components providing a greater amount of genealogical information of sires(23), since there was more than $50 \%$ of unknown fatherhoods at NBDI regarding MHA. Phenotypic variances were higher in the MHA due to environmental variability was also higher. Moreover, the variance of the permanent environment in NBDI was nil, as the MHA for the standardized production, in agreement with the results of Montaldo and Torres(24); however, in the MP5 of MHA and the MP5 and MP5std of the NBPD permanent environmental variances were high, similar to those estimated by Valencia et al(25), which may suggest the need to revise the adjustment factors subsequent to the first lactation.

The estimated heritabilities (Table 4) were moderate to low, for lactations at first birth and for the first five lactations. For MP1 the MHA had a value of $0.179 \pm 0.015$ similar to the value of NBPD which was $0.176 \pm 0.009$, while the highest value was for NBDI with a heritability of $0.497 \pm 0.019$; this because the additive variance was greater, indicating greater

Cuadro 3. Varianzas aditivas, de ambiente permanente, residual y fenotípica para cada uno de los modelos Table 3 Additive, permanent environment, residual and phenotypic variances for each of the models

\begin{tabular}{|c|c|c|c|c|c|}
\hline Database & Variances & MP1std & MP1 & MP5std & MP5 \\
\hline & Additive & $1,312,950$ & 763,031 & $1,709,590$ & 692,852 \\
\hline NBDI & Perm. environment & & & 0.4969 & 0.3104 \\
\hline \multirow[t]{3}{*}{$(n=120,217)$} & Residual & $2,4304,00$ & 769,404 & $2,511,420$ & $1,232,220$ \\
\hline & Phenotypic & $3,743,350$ & $1,532,435$ & $4,221,010$ & $1,925,072$ \\
\hline & Additive & $1,040,400$ & 560,153 & $2,420,520$ & 760,009 \\
\hline MHA & Perm. environment & & & 0.9573 & 693,293 \\
\hline \multirow[t]{3}{*}{$(n=43,668)$} & Residual & $3,508,570$ & $2,555,570$ & $3,478,580$ & $2,573,440$ \\
\hline & Phenotypic & $4,548,970$ & $3,115,723$ & $5,899,101$ & $4,026,742$ \\
\hline & Additive & $1,032,640$ & 338,278 & $1,556,620$ & 413,620 \\
\hline \multirow{3}{*}{$\begin{array}{l}\text { NBPD } \\
(n=163,885)\end{array}$} & Perm. environment & & & 242,763 & 397,018 \\
\hline & Residual & $2,905,170$ & $1,576,530$ & $2,812,440$ & $1,646,990$ \\
\hline & Phenotypic & $3,937,810$ & $1,914,808$ & $4,611,823$ & $2,457,628$ \\
\hline
\end{tabular}

$\mathrm{NBDI}=$ Database of the National Bank of Dairy Information, MHA= Database of the Holstein Association of Mexico, NBPD= National program that joints NBDI and MHA. MP1 and MP5= Total milk production from the first and the fifth lactations; MP1std and MP5std= Standardized milk productions from the first and the fifth lactations. 
lactancia por parte del BNIL respecto a la AHM. Sin embargo, en el PNMG las varianzas aditivas en todos los casos fueron las más bajas, debido a que la variabilidad entre los sementales en el PNMG también era menor. Las heredabilidades fueron similares a la AHM debido a que la varianza fenotípica también disminuyó, por lo que la información que aporta la base de la AHM tiene una influencia alta en las evaluaciones y estimación de componentes genéticos al aportar una mayor cantidad de información genealógica de los sementales(23), dado que hubo más del $50 \%$ de paternidades desconocidas en BNIL con respecto a la AHM. Las varianzas fenotípicas fueron más altas en la AHM debido que la variabilidad ambiental también fue mayor. Por otro lado, la varianza del ambiente permanente en el BNIL fue nula al igual que en la AHM para la producción estandarizada, en coincidencia con los resultados de Montaldo y Torres(24); sin embargo, en la PL5 de la AHM y en la PL5 y PL5std del PNMG las varianzas de ambiente permanente fueron altas, similares a las estimadas por Valencia et al(25), lo que puede sugerir la necesidad de revisar los factores de ajuste de las lactancias posteriores a la primera.

Las heredabilidades estimadas (Cuadro 4), fueron de moderadas a bajas, tanto para las variability in the selection of sires; and in all cases NBDI environmental variability was less compared with MHA and NBPD.

The MP1std showed heritabilities for MHA of $0.228 \pm 0.017$, for NBPD an intermediate value of $0.262 \pm 0.012$ and for the NBDI the highest value with $0.350 \pm 0.017$. Heritability estimates in this work for MP1 of the MHA and NBPD are similar to those obtained by Montaldo et al(26) of $0.17 \pm 0.02$, and higher than the estimation obtained by Valencia et al(6) of $0.13 \pm 0.03$ for Holstein cattle in Mexico, while the heritability for MP1 of the NBDI is in the rank calculated by Mark( 4 ) of 0.19 to 0.59 and the estimations of other countries(4,27-29).

The heritabilities for MP1std of the MHA and the NBPD are close to those obtained by Valencia et $a /(30)$ of $0.25 \pm 0.01$ and lower than the estimations of other researchers of $0.29 \pm 0.14(9)$, while the heritability of MP1std from NBDI is higher than the calculations made by the same authors, even when it is between the rank of heritabilities obtained by Mark(4). The differences in this study between the heritabilities estimated for MP1std in the three datasets are probably due to the different number of observations among them, and because of environmental differences among herds of the MHA and NBDI.

Cuadro 4. Heredabilidades $\left(h^{2}\right)$ y repetibilidades $(t)$ con sus errores estándar (se) para la producción de leche total y estandarizada a la primera y quinta lactancia

Table 4 Heritabilities $\left(h^{2}\right)$ and repeatabilities $(t)$ with their standard errors (se) for total milk production and standardized milk production from the first and fifth lactation

\begin{tabular}{lcccccccccccc}
\hline & \multicolumn{4}{c}{ NBDI $(\mathrm{n}=120,217)$} & \multicolumn{4}{c}{ MHA $(\mathrm{n}=43,668)$} & \multicolumn{4}{c}{ NBPD $(\mathrm{n}=163,885)$} \\
& $h^{2}$ & se & $t$ & se & $h^{2}$ & se & $t$ & se & $h^{2}$ & se & $t$ & se \\
\hline MP1 & 0.497 & 0.019 & - & - & 0.179 & 0.015 & - & - & 0.176 & 0.009 & - & - \\
MP1std & 0.350 & 0.017 & - & - & 0.228 & 0.017 & - & - & 0.262 & 0.012 & - & - \\
MP5 & 0.359 & 0.003 & 0.359 & 0.003 & 0.188 & 0.010 & 0.360 & 0.004 & 0.168 & 0.006 & 0.329 & 0.002 \\
MP5std & 0.405 & 0.002 & 0.405 & 0.002 & 0.410 & 0.004 & 0.410 & 0.004 & 0.337 & 0.008 & 0.390 & 0.002 \\
\hline
\end{tabular}

$\mathrm{NBDI}=$ Database of the National Bank of Dairy Information, MHA= Database of the Holstein Association of Mexico, NBPD= National program that joints NBDI and MHA. MP1 and MP5= Total milk production from the first and the fifth lactations, MP1std and MP5std= Standardized milk productions from the first and the fifth lactations. 
lactancias a primer parto como para las lactancias de los primeros cinco partos. Para la PL1 la AHM tuvo un valor de $0.179 \pm 0.015$ similar al valor del PNMG que fue de $0.176 \pm$ 0.009 , mientras que el valor más alto fue para el BNIL con una heredabilidad de $0.497 \pm 0.019$, esto debido a que las varianza aditiva fue mayor, indicando una mayor variabilidad en la selección de sementales; y en todos los casos la variabilidad ambiental del BNIL fue menor con respecto a AHM y PNMG. La PL1std mostró heredabilidades para la AHM de $0.228 \pm 0.017$, para el PNMG un valor intermedio de $0.262 \pm$ 0.012 y para el BNIL el valor más alto con $0.350 \pm 0.017$. Las heredabilidades estimadas en este trabajo para PL1 de la AHM y el PNMG son similares a la obtenida por Montaldo et al(26) de $0.17 \pm 0.02$ y mayores a la obtenida por Valencia et a(6) de $0.13 \pm 0.03$ para ganado Holstein en México, mientras que la heredabilidad para PL1 de la BNIL se encuentra en el rango calculado por $\operatorname{Mark}(4)$ de 0.19 a 0.59 y las estimadas en otros países $(4,27,28,29)$.

Las heredabilidades para la PL1std de la AHM y del PNMG son cercanas a la obtenidas por Valencia et $a(30)$ de $0.25 \pm 0.01$ y menores a las estimadas por otros investigadores(9) de $0.29 \pm 0.14$, mientras que la heredabilidad del PL1std del BNIL es mayor a las calculadas por los mismos autores, aun cuando se encuentra dentro del rango de heredabilidades obtenidas por Mark(4). Las diferencias entre las heredabilidades estimadas para PL1std en los tres conjuntos de datos de este estudio se deben probablemente al diferente número de observaciones entre las bases de datos, y a las diferencias ambientales entre los hatos de la AHM y del BNIL.

En cuanto a la PL5 el valor más bajo fue para el PNMG de $0.168 \pm 0.006$, seguido de la AHM con $0.188 \pm 0.010$ y el valor máximo lo tuvo el BNIL con $0.359 \pm 0.003$. En la PL5std el PNMG obtuvo el valor más bajo con $0.337 \pm$ 0.008 después el BNIL con $0.405 \pm 0.002$ y con un valor similar la AHM con $0.410 \pm 0.004$. El valor de heredabilidad más bajo en el PNMG
Regarding MP5 the lowest value was for the NBPD of $0.168 \pm 0.006$, followed with $0.188 \pm$ 0.010 from the MHA and the maximum value was for the NBDI with $0.359 \pm 0.003$. In MP5std the NBPD had the lowest value $0.337 \pm 0.008$, then the NBDI with $0.405 \pm 0.002$ and with a similar value the MHA with $0.410 \pm 0.004$. The lowest value of heritability at NBPD is explained by reduced additive variability and a phenotypic variance similar to those of the MHA and the NBDI, due to the difference in quantity and quality of the genealogical information between databases. The estimated heritability for MP5 in the NBPD and the MHA is similar to that estimated in other study(31) of $0.18 \pm 0.021$ and the estimated by López et al(9) of 0.15 \pm 0.05 using repeatability models, while the heritability of MP5 in NBDI was superior to these values. The heritabilities of MP5std from the MHA, the NBPD and the NBDI were higher than those obtained in analysis of multiple lactations adjusted adulthood(32) of $0.26 \pm 0.09$ in a Holstein population of northern in Mexico. Furthermore, the heritabilities of MP5std for the three data sets were within the range of values $(0.14 \pm 0.03$ to $0.42 \pm 0.05)$ calculated by Valencia et a(30) for different geographic regions of Mexico. For the repeatabilities of the first five lactations unstandardized (MP5), the NBPD had the lowest value $0.329 \pm 0.002$, followed by $0.359 \pm 0.003$ of the NBDI and $0.360 \pm$ 0.004 from the MHA. While for MP5std the lowest value of repeatability was observed in NBPD with $0.390 \pm 0.002$, was then NBDI with $0.405 \pm 0.002$ and followed by the MHA with $0.410 \pm 0.004$. The repeatability of the NBPD for MP5 is similar to that estimated by others $(9)$ of $0.32 \pm 0.03$. MP5std values of the three databases and MP5 of the MHA are within the range of values of repeatabilities mentioned in other researches of 0.36 to $0.51(30)$.

Means, standard deviations, minimums and maximums of accuracies from evaluations of bulls in common of the three databases deviations are presented in Table 5. Accuracies averages of NBPD were higher than those of NBDI and the MHA. Also, the averages of NBDI 
es explicado por una variabilidad aditiva menor y una varianza fenotípica similar a las de la AHM y el BNIL, debido a la diferencia en cantidad y calidad de la información genealógica entre las bases de datos. La heredabilidad estimada para PL5 en el PNMG y la AHM es similar a la estimada en otro trabajo(31) de $0.18 \pm 0.021$ y a la estimada por López et al(9) de $0.15 \pm 0.05$ usando modelos de repetibilidad, mientras que la heredabilidad de PL5 en el BNIL fue superior a estos valores. Las heredabilidades de PL5std de la AHM, del BNIL y del PNMG fueron mayores a las obtenidas en análisis de lactancias múltiples ajustadas a edad adulta(32) de $0.26 \pm 0.09$ en una población Holstein del norte de México. Por otro lado, las heredabilidades de PL5std para los tres conjuntos de datos estuvieron dentro del rango de valores $(0.14 \pm 0.03$ a $0.42 \pm$ $0.05)$ calculado por Valencia et al(30) para diferentes regiones geográficas de México. Para las repetibilidades de las primeras cinco lactancias sin estandarizar (PL5), el PNMG tuvo el valor más bajo con $0.329 \pm 0.002$, seguido por el BNIL con $0.359 \pm 0.003$ y la AHM con 0.360 \pm 0.004 . En tanto que para la PL5std el valor más bajo de repetibilidad se observó en el PNMG con un valor de $0.390 \pm 0.002$, después estuvo el BNIL con $0.405 \pm 0.002$ y seguido por la AHM con $0.410 \pm 0.004$. La repetibilidad del PNMG para PL5 es similar al estimado por otros(9) de $0.32 \pm 0.03$. Los valores de PL5std de las tres bases de datos y de PL5 de la AHM están dentro del rango de valores de repetibilidad mencionados en otras investigaciones de 0.36 a $0.51(30)$.

Las medias, desviaciones estándar, mínimos y máximos de las precisiones de las evaluaciones de los toros en común de las tres bases de datos se presentan en el Cuadro 5. Los promedios de las precisiones del PNMG fueron superiores a los del BNIL y a los de la AHM. Así mismo, los promedios de las precisiones del BNIL fueron mayores que los de la AHM. La media más alta se estimó para el PNMG en PL5std con 0.86, mientras que la media más baja fue para la AHM en PL1 con 0.64. La
Cuadro 5. Media, desviación estándar (SD), mínimo y máximo, para las precisiones de los valores genéticos de los sementales en común en las tres bases de datos

Table 5. Mean, standard deviation (SD), minimum and maximum, of accuracies of breeding values for sires in common in the three datasets

\begin{tabular}{llccc}
\hline & Statistic & NBDI & MHA & NBPD \\
\hline & Mean & 0.7542 & 0.6498 & 0.7780 \\
MP1 & SD & 0.1784 & 0.2204 & 0.1686 \\
$\mathrm{n}=601$ & Minimum & 0.3306 & 0.0095 & 0.2088 \\
& Maximum & 0.9969 & 0.9773 & 0.9916 \\
& & & & \\
& Mean & 0.7482 & 0.6758 & 0.8171 \\
MP1std & SD & 0.1918 & 0.2229 & 0.1549 \\
$\mathrm{n}=601$ & Minimum & 0.2770 & 0.0001 & 0.2542 \\
& Maximum & 0.9955 & 0.9821 & 0.9944 \\
& & & & \\
& Mean & 0.7847 & 0.6980 & 0.8049 \\
MP5 & SD & 0.1740 & 0.1969 & 0.1524 \\
$\mathrm{n}=907$ & Minimum & 0.2971 & 0.1046 & 0.3154 \\
& Maximum & 0.9974 & 0.9908 & 0.9945 \\
& & & & \\
& Mean & 0.7947 & 0.7742 & 0.8634 \\
MP5std & SD & 0.1702 & 0.1864 & 0.1288 \\
$\mathrm{n}=907$ & Minimum & 0.3149 & 0.1590 & 0.4307 \\
& Maximum & 0.9978 & 0.9977 & 0.9973 \\
\hline
\end{tabular}

$\mathrm{NBDI}=$ Database of the National Bank of Dairy Information, $\mathrm{MHA}=$ Database of the Holstein Association of Mexico, $\mathrm{NBPD}=$ National program that joints NBDI and MHA. MP1 and MP5= Total milk production from the first and the fifth lactations, MP1std and MP5std= Standardized milk productions from the first and the fifth lactations

accuracies were higher than those of the MHA. The highest average was estimated for NBPD in MP5std with 0.86, while the lowest mean was for the MHA in MP1 with 0.64. Integrating information from NBDI and MHA in the NBPD increased the average accuracies of the predictions of genetic values of sires represented in the three populations, due to an increase in the number of registers and kinship relation by sire.

Correlation coefficients by rank of Spearman with their respective significance levels are shown in Table 6. When all sires in common were considered for the MHA and NBDI $(n=601)$, 
Cuadro 6. Coeficientes de correlación por rangos de Spearman y sus respectivos niveles de significancia $(P)$ para los valores genéticos de los sementales en común de las tres bases de datos

Table 6. Correlation coefficients by Spearman ranks and their significances $(P)$ for breeding values of sires in common in the three databases

\begin{tabular}{lcccc}
\hline & MP1 & MP1std & MP5 & MP5std \\
\hline$(\mathrm{n}=601)$ & & & & \\
MHA-NBDI & 0.2944 & 0.3874 & 0.3706 & 0.4665 \\
$P$ & $<0.0001$ & $<0.0001$ & $<0.0001$ & $<0.0001$ \\
MHA-NBPD & 0.8418 & 0.7943 & 0.7696 & 0.8012 \\
$P$ & $<0.0001$ & $<0.0001$ & $<0.0001$ & $<0.0001$ \\
NBDI-NBPD & 0.6369 & 0.7583 & 0.7705 & 0.8220 \\
$P$ & $<0.0001$ & $<0.0001$ & $<0.0001$ & $<0.0001$ \\
$(\mathrm{n}=60)$ & & & & \\
$10 \%$ top of MHA vs NBDI & 0.0290 & -0.1260 & 0.0072 & 0.0503 \\
$P$ & 0.8259 & 0.3374 & 0.9566 & 0.7025 \\
$10 \%$ top of NBDI vs MHA & 0.0914 & 0.1745 & 0.0462 & 0.0600 \\
$P$ & 0.4874 & 0.1824 & 0.7257 & 0.6487 \\
$10 \%$ top of NBPD vs MHA & 0.6241 & 0.2362 & 0.6649 & 0.4063 \\
$P$ & $<0.0001$ & 0.0692 & $<0.0001$ & 0.0013 \\
$10 \%$ top of NBPD vs NBDI & 0.2705 & 0.3429 & 0.1668 & 0.2892 \\
$P$ & 0.0366 & 0.0073 & 0.2028 & 0.0250 \\
\hline
\end{tabular}

$\mathrm{NBDI}=$ Database of the National Bank of Dairy Information, MHA= Database of the Holstein Association of Mexico, NBPD $=$ National program that joints NBDI and MHA. MP1 and MP5= Total milk production from the first and the fifth lactations, MP1std and MP5std= Standardized milk productions from the first and the fifth lactations.

integración de la información del BNIL y de la AHM en el PNMG incrementó el promedio de las precisiones de las predicciones del valor genético de los sementales representados en las tres poblaciones, debido a un aumento del número de registros y de relaciones de parentesco por semental.

Los coeficientes de correlación por rangos de Spearman con sus respectivos niveles de significancia se muestran en el Cuadro 6. Cuando se tomaron en cuenta todos los sementales en común para la AHM y el BNIL $(n=601)$, todas las correlaciones estimadas fueron positivas $(P<0.0001)$ de bajas a moderadas. La correlación m13do se seleccionó al $10 \%$ superior en el PNMG, las correlaciones entre los valores predichos los toros en común all estimated correlations were positive $(P<0.0001)$ low to moderate. The highest correlation (0.84) was estimated for MP1 between the MHA and the NBPD, and the lowest (0.29) between the MHA and the NBDI. When top $10 \%$ was selected from both MHA and NBDI the correlations were not significant. When $10 \%$ higher was selected in the NBPD, the correlations between the values predicted from bulls in common in the NBPD and the MHA were positive and significant for all characters $(P<0.0001)$ except for MP1std $(P=0.0692)$. In contrast, correlations between predicted values from top $10 \%$ of bulls in the NBPD and the NBDI were significant for all characters $(P<0.0001)$ except for MP5 $(P=0.2028)$. The highest correlation was between the top $10 \%$ of NBPD and MHA with $0.6649(P<0.0001)$, 
en el PNMG y en la AHM fueron positivas y significativas para todos los caracteres $(P<0.0001)$, excepto para PL1std $(P=0.0692)$. En cambio, las correlaciones entre los valores predichos del $10 \%$ superior de los toros en el PNMG y en el BNIL fueron significativas para todos los caracteres $(P<0.0001)$, excepto para PL5 $(P=0.2028)$. La correlación más alta fue aquélla entre el $10 \%$ superior del PNMG y de la AHM con $0.6649(P<0.0001)$, y la correlación más baja se estimó para el $10 \%$ superior del PNMG vs BNIL con 0.2705 ( $P=0.0366)$. Los valores bajos de las correlaciones entre los toros en común en la AHM y el BNIL sugieren niveles de producción diferentes de la progenie de estos sementales en estas dos poblaciones, y resaltan la necesidad de verificar la consistencia de la información del BNIL antes de integrar las bases de datos en las evaluaciones genéticas para obtener resultados más confiables, corrigiendo cuando sea necesario por la heterogeneidad de varianzas observada en este estudio. Esto podría ser un indicador de una interacción genotipo ambiente debido a diferencias en condiciones ambientales (clima, nutrición, manejo) en hatos de la AHM y del BNIL.

Las heredabilidades y repetibilidades estimadas fueron similares a las reportadas anteriormente en México, donde se contó con un número menor de registros. La inclusión del Banco Nacional de Información Lechera y de la Asociación Holstein de México en el Programa Nacional de Mejoramiento Genético mejoró la precisión de los valores genéticos de los sementales para producción de leche, alterando de manera importante las predicciones de los valores genéticos de los sementales evaluados, y permitió la predicción de los valores genéticos de un mayor número de sementales con progenie en México; sin embargo, las diferencias reportadas entre la AHM y el BNIL sugieren la necesidad de verificar la consistencia de la información del BNIL y de los factores de ajuste, antes de integrar las bases de datos para obtener resultados más confiables. and the lowest correlation was estimated for the $10 \%$ higher of the NBPD vs NBDI with $0.2705(P=0.0366)$. Low values of the correlations between bulls in common in the MHA and NBDI suggest different levels of production of the progeny of these sires in these two populations and highlight the need to verify the consistency of the information before integrating NBDI genetic data bases for more reliable results correcting if needed for heterogeneity of variances observed in this study evaluations. This could be an indicator of genotype environment interaction due to differences in environmental conditions (climate, nutrition, management) in herds of MHA and NBDI.

Heritability and repeatability estimates were similar to those reported previously in Mexico, where fewer records were used. The inclusion of the National Bank of Dairy Information and Holstein Association of Mexico at the National Breeding Program of Dairy cattle improved the accuracy of breeding values of sires for milk production, significantly altering the predictions of genetic values of sires evaluated, and allowed the prediction of breeding values of a greater number of sires with progeny in Mexico; however, the reported differences between the MHA and NBDI suggest the need to verify the consistency of the information of the NBDI and the adjustment factors before integrating databases to obtain more reliable results.

\section{ACKNOWLEDGEMENTS}

The research was supported by the Consejo Nacional de los Recursos Genéticos Pecuarios, the Coordinación General de Ganadería SAGARPA and the Asociación Holstein de México through access to their databases. The first author received a Master's scholarship from the CONACYT in support of this research.

End of english version 


\section{AGRADECIMIENTOS}

Se agradece al Consejo Nacional de los Recursos Genéticos Pecuarios, a la Coordinación General de Ganadería - SAGARPA y a la Asociación Holstein de México, el apoyo en la realización de este proyecto al facilitar las bases de datos. Así como al CONACyT por otorgar una beca de maestría al primer autor.

\section{LITERATURA CITADA}

1. Hofer A. Variance component estimation in animal breeding: a review. J Anim Breed Genet 1998;115:247-265.

2. Hansen LB. Consequences of Selection for Milk yield from a geneticist's viewpoint. J Dairy Sci 2000;83:1145-1150.

3. Mourits MCM, Huirne RBM, Dijkhuizen AA, Kristenses AR, Galligan DT. Economic optimi-zation of dairy heifer management decisions. Agric Sys 1999;61:17-31.

4. Mark T. Applied genetic evaluations for production and functional traits in dairy cattle. J Dairy Sci 2004;87:26412652.

5. VanRaden PM. Invited review: Selection on merit to improve lifetime profit. J Dairy Sci 2004;87:3125-3131.

6. Valencia PM, Montaldo VH, Ruiz LF. Parámetros genéticos para características de conformación, habilidad de permanencia y producción de leche en ganado Holstein en México. Téc Pecu Méx 2008;46(3):235-248.

7. Abubakar BY, McDowell RE, Van Vleck LD. Interaction of genotype and environment for breeding efficiency and milk production of Holsteins in México and Colombia. Trop Agric (Trinidad) 1987;64:17-22.

8. Sosa FC. Estimación de Índice de herencia y constancia para producción de leche y tipo en un hato Holstein del noroeste de México [tesis licenciatura]. México (DF) México: Universidad Nacional Autónoma de México; 1980.

9. López OR, Castillo JH, Montaldo VH. Covarianzas genéticas y fenotípicas para días abiertos y características de la curva de lactancia en vacas Holstein en el norte de México. Vet Méx 2009;40(4):343-356.

10. Carvajal HM, Valencia HE, Segura CJ. Duración de la lactancia y producción de leche de vacas Holstein en el estado de Yucatán, México. Rev Biomed 2002;13:25-31.

11. Montaldo $\mathbf{V H}$, Torres NS. Repetibilidad de la producción de leche e intervalo entre partos en una población de vacas Holstein en México. Arch Zootec 1993;42:361-366.

12. Asociación Holstein de México. Resumen ejecutivo, Programa Nacional de Mejoramiento Genético de Bovinos Productores de Leche. SAGARPA, CONARGEN, Santiago de Querétaro, México. 2010.
13. Microsoft. C\# Programming Guide, Visual C\#, MSDN. Microsoft Corp. USA. 2012.

14. SAS. Institute, Inc. SAS/STAT Users Guide, version 9.2 ed. Cary, North Carolina, USA: SAS Institute Inc., 1997.

15. García E. Modificaciones al sistema de clasificación climática de Köpen para adaptarlo a las condiciones de la República Mexicana. Instituto de Geografía. UNAM. México DF 2004.

16. Améndola $R$, Castillo $E$, Arturo P. Pérfiles por país del recurso pastura / forraje. FAO. 2005.

17. Améndola RD. A dairy system based on forages and grazing in temperate Mexico [PhD thesis]. Wageningen University, The Netherlands. 2002.

18. Harville DA. Maximum likelihood approaches to variance component estimation and to related problems. J Am Stat Assoc $1977 ; 72: 320-340$.

19. Gilmour AR, Thompson R, Cullis RR. AIREML, an efficient algorithm for variance parameter estimation in linear mixed models. Biometrics 1995;51:1440-1450.

20. Gilmour AR, Gogel, BJ, Cullis, BR, Thompson, R. ASReml User Guide Release 3.0 VSN International LTD, Harpenden AL5 2JQ, UK, 2009.

21. Henderson CR. Application for linear models in animal breeding. Canada: University of Guelph; 1984.

22. Mrode RA, Thompson R. Linear models for the prediction of animal breeding values. Second Edition, CABI Publishing, USA, 2005

23. Everett $R$, Keown. Mixed model sire evaluation with dairy cattle-experience and genetic gain, J Anim Sci 1984;59(2) 529-541.

24. Montaldo VH, Torres NS, Repetibilidad de la producción de leche e intervalo entre partos en una población de vacas Holstein en México. Nota Breve. Arch Zootec 1993;42:361366.

25. Valencia PM, Ruiz LF, Montaldo VH, Genetic and environmental variance components for milk yield across regions, time periods and herd levels for Holstein cattle in México. Revista Cientifica, FCV-LUZ 2004;14;5:404-411.

26. Montaldo HH, Castillo JH, Valencia PM, Cienfuegos RE, Ruiz LF. Genetic and enviromental parameters for milk production, udder health, and fertility traits in mexican Holstein cows. J Dairy Sci 2010;93:2168-2175.

27. Oliveira BI, Araújo CJ, Napolis CC, Nogara RP, Braccini NJ, Lunardini CL. Genetic parameters for production traits in primarous Holstein cows estimated by random regression models. R Bras Zootec 2011;40(1):85-94.

28. Ramalho de Freitas MA, Moura DF, Lobo RB, Wilcox CJ. Genetic parameters for Holstein milk production in Brazil. Rev Brasil Genet 1982;1:147-155.

29. Albuquerque LG, Dimov G, Keown JF, Van Vleck LD. Estimates using an animal model of (Co)variances for yields of milk, fat, and protein for the first Lactation of Holstein cows in California and New York. J Dairy Sci 1995;78:15911596.

30. Valencia PM, Ruiz LF, Montaldo VH. Estimación de parámetros genéticos para características de longevidad y producción de leche en ganado Holstein en México, Interciencia 2004;29(1):52-56.

31. Vargas LB, Gamboa ZG. Estimación de tendencias genéticas e interacción genotipo $x$ ambiente en ganado lechero de Costa Rica. Téc Pecu Méx 2008;46(4):371-386.

32. Palacios EA, Rodriguez AF, Jimenez CJ, Espinoza VJ, Nuñez DR. Evaluación genética de un hato Holstein en Baja California Sur, utilizando un modelo animal con mediciones repetidas. Agrociencia 2001;35;347-353. 
